\title{
The Decline of the Secular University
}

\section{By C. John Sommerville, Oxford University Press Inc., New York, NY; 2006; ISBN: 0-19-530695-3; 160 pages; Price: \$22.00}

International Journal of Educational Advancement (2007) 7, 68-70.

doi:10.1057/palgrave.ijea.2150047

As goes Harvard, so follows American Higher Education. If this statement is to be believed, then the recent debate of whether to include a "reason and faith" requirement in Harvard's core curriculum may signal a shift towards the elevation of religion in the academy's hallowed halls. In response to this change, a Harvard professor acknowledged that "[religion] is something that secular universities may not be preparing students to deal with." "This curricular discussion should come as no surprise to C. John Sommerville whose "The Decline of the Secular University" outlines the negative impact secular thought has on American colleges and universities. Owing much in style and philosophy to Alasdair MacIntyre, the book is part history, part criticism, ultimately contending that secularism cannot instruct one on living life.

Central to Sommerville's argument is the differentiation between secularization and secularism. While the former is "the separation of religion from various aspects of life and thought," the latter is an ideology seeking to accomplish and bring secularization to bear. As a historian, Sommerville tells the reader that at times, secularization and religion were compatible. On the other hand, secularism's goal is the termination of religion all together. Although students may still study religion in colleges and universities, Sommerville suggests they are more likely to encounter religion as an object of criticism than one of belief. For him, when secularism replaced religion, universities became its churches and the professoriate its ministers.

Sommerville is not suggesting a return to medieval-style religious education, rather he asserts that religious voices are valid in contemporary society. As it stands, academia now is in a postsecular era where "fashion" dominates discourse without acknowledging the force of religion. For the author, these "fashions" are merely fads that do not embody the attitudes of Americans and their society. In light of the fact that a majority of Americans report themselves to be religious, also electing leaders claiming to be religious, the academy appears aloof to the general population. In this argument, Sommerville revisits the religious voices from the Progressive Era where individuals believed universities should not only educate citizens, but also prepare the country's political leaders. While this claim 
reflects the belief that education is a public good, it suggests that our institutions currently no longer supply the public with that which it believes is good. At a time when military conflicts stemming from religious differences dominate international headlines, secularism not only ill prepares one's engagement in the world, but is clearly not succeeding in eliminating religion. While illuminating us with anecdotal accounts of frustrated students seeking his understanding ear, Sommerville concludes that students are taught to leave their religious beliefs at the door, and are only able to pick them up after the final examination. In this sense, secularism fails under the perspective of education as a private good. If graduates are to make sense of the world, they must be able to navigate how religion impacts actions.

According to law, public educational institutions can only teach about religions rather than instruct how to be religious. In contrast, the author notes that secularism's entrance into academic discourse exists only in the form of indoctrination, suggesting that academics should teach about secularism inasmuch as it too possesses a distinct history, assumptions, and methodology. If the postmodernist perspective is correct, then secularism as an ideology is but one of multiple viewpoints rather than the metanarrative it poses to be. It is postmodernity's rise within the academy that led to our current "postsecular" predicament. While Sommerville fails to elaborate fully on this notion, it suggests that ultimate change within secular universities will result from internal academic discourse rather than the aforementioned external pressures.

Recently, the University of California at Los Angeles' Higher Education Research Institute released a survey whose findings suggest that 81 percent of faculty members consider themselves "spiritual." Neil Gross and Solon Simmon's survey of professors suggests that only 10 percent of professors do not believe in God. ${ }^{2}$ This is quite different from the academics Sommerville describes as indoctrinating undergraduates. That said, one speculates that if Sommerville is right, their "professionalism" requires them to remove spirituality from their work so as to comply with the secular rules of their workplace. With this in mind, Sommerville offers little guidance as to what to do with the current professoriate in an age of postsecularism, a working class whose professional training included learning to engage in discourse secularly.

One possibility ignored throughout the book is that today's college going students may enter their undergraduate careers ripe for, if not accustomed to, secularism. Secularism's domination of academic thought throughout the twentieth century impacted the educations and shaped the attitudes of several generations. As Sommerville repeats, most of the nation reports itself as religious, yet people familiar with secularism raised today's students. With the possible exception of first generation college students who are likely further disadvantaged by their unfamiliarity with secular thought, secularism is not as shocking to today's students as it was a hundred years ago. The possibility exists that religious voices in an academic setting would challenge today's students in 
ways that secularism challenged their ancestors.

As a historian at a state flagship institution, the strength of Sommerville's argument is that his voice comes from within the academy, the intended audience being not religious fundamentalist, but educators and autodidacts paralyzed by the contemporary academic climate of "fashion." While little is said of the responsibility of religious institutions in the secular argument, it is clear that Sommerville's challenge is to public colleges and universities. He succeeds in his aims to elaborate how and why Higher Education is "out of touch," yet it is difficult for one to believe that his vision of American higher education could ever come to fruition.

Notes

${ }^{1}$ From "Harvard Panel proposes requiring the study of religion and American history," The Chronicle of Higher Education 2006, 53, 8, p. A49. ${ }^{2}$ From "Professors are more religious than some might assume, survey finds," The Chronicle of Higher Education 2006, 53, 9, p. A26.

T. Austin Lacy

Vanderbilt University

Otter Falls Road, Sewanee, TN, USA 